\title{
The monastic mosaic at Mount Nebo, Jordan: biogeochemical and epigraphical evidence for diverse origins
}

Margaret Judd ${ }^{1, *}$, Lesley Gregoricka ${ }^{2} \&$ Debra Foran $^{3}$

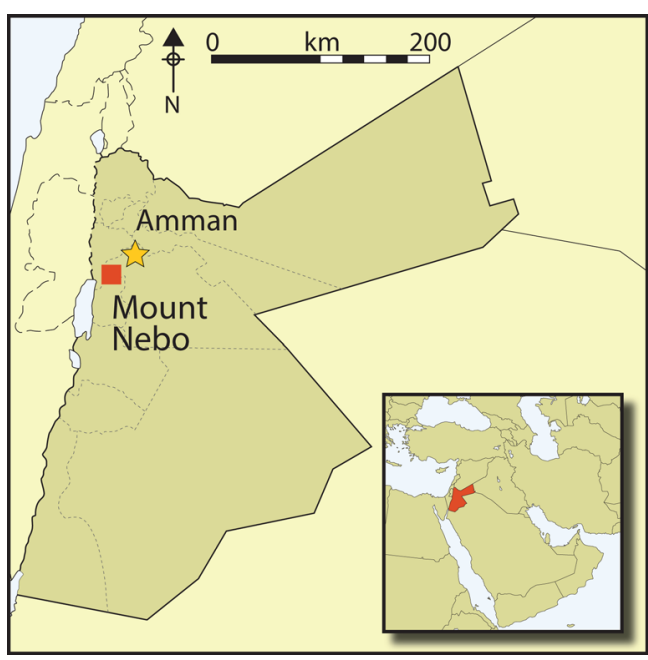

Due to its association with the Prophet Moses, the Byzantine monastery of Mount Nebo (AD 491-640) was (and still is) a popular pilgrimage destination in the southern Levant. Although foreign monastics were probably attracted to the monastery, communal interment has obscured the diverse origins of the people buried here. The authors use biogeochemical and onomastic inquiry to examine a cosmopolitan monastic 'mosaic' of identity. Isotopic analyses of tooth enamel reveal the presence of a sizeable number ( 47 per cent) of non-local migrants buried at the site. Mosaic inscriptions provide further evidence for the ethnic diversity of the population.

Keywords: Jordan, Mount Nebo, Byzantine, monasticism, isotopic analysis

\section{Introduction}

Early Christian monasticism promoted a collective identity, in which personal identity was blurred by clothing, gesture and modified appearance-the monastic 'social skin' (Turner 2012). Individuality was correspondingly denied in death through secondary communal burial, where the skeletal remains of individuals were commingled to preserve a corporate identity. As a result, individually lived experiences shaped by gender, ethnicity and place of origin were masked, and bioarchaeological investigations rendered problematic but not impossible. While secondary interments of skeletal remains among Early Christian monastics are well

1 Department of Anthropology, University of Pittsburgh, 3302 South Bouquet Street, Pittsburgh, PA 15260, USA

2 Department of Sociology, Anthropology \& Social Work, The University of South Alabama, 5991 USA Drive North Mobile, $A L$ 36688, USA

3 Department of Archaeology and Heritage Studies, Wilfrid Laurier University, 75 University Avenue West, Waterloo, Ontario N2L 3C5, Canada

* Author for correspondence (Email: mjudd@pitt.edu) 
known in the southern Levant, bioarchaeological research has been constrained by the commingled nature of these collections, as well as by repatriation efforts (Judd 2009a; Perry 2012; Sheridan 2017). There are some notable exceptions from Israel (e.g. Hershkovitz et al. 1993; Gregoricka \& Sheridan 2013; Sheridan \& Gregoricka 2015), while monastic life in Jordan is inferred only from architectural and artefactual information (e.g. MacDonald 2010) and from a recent assessment of individuals from the Sanctuary of Agios Lot at Deir 'Ain 'Abata (Gruspier 2012).

The location of the church and monastic complex at Mount Nebo, on the outskirts of Madaba in Jordan, is particularly suited for bioarchaeological investigation of Early Christian identity (Figure 1). Following the legitimisation of Christianity in the fourth century $\mathrm{AD}$, the southern Levant became a destination for lay pilgrims-particularly wealthy Christians who frequently chronicled their travels (Wilkinson 2002; Dietz 2005). Madaba served as a crossroads for those who passed between Egypt and Syria (Hirschfeld 2006), and the town is renowned for its detailed mosaic map of Holy Land pilgrimage sites (c. $\mathrm{AD} 560$ ) that escaped the waves of iconoclasm beginning in the eighth century $\mathrm{AD}$ (Avi-Yonah 1954).

Monastics were also attracted to this pilgrimage site and region, but the communal funerary interments at Mount Nebo have obscured the ethnic diversity of those buried there. Here we remove the communal 'social skin' through the integration of multiple lines of evidence (skeletal demographics, biogeochemical analyses, onomastics and local landscape) to test the hypothesis that Mount Nebo was cosmopolitan in nature, attracting non-local pilgrims and monastics alike, due, in part, to the site's association with the Prophet Moses.

\section{Byzantine monastery of Mount Nebo}

The Christian monastery on Mount Nebo (AD 491-640) commemorates the place from where the Prophet Moses viewed the Promised Land, as well as the site of his burial (Deut. 34.1-6; King James Bible Online 2017). This important pilgrimage site was at the centre of a network of monasteries that flourished in central Transjordan during the Byzantine period (Foran 2005a). The monastic community was described in the historical accounts of many pilgrims and travellers to the Holy Land, who spoke of Mount Nebo's spiritual influence and renown (Wilkinson 2002). The first description is attributed to the Spanish pilgrim Egeria (c. late fourth century AD) (Gingras 1970), who, with her clerical entourage from Jerusalem, visited the cave cells of the holy men in the valley; those of the group who were physically able, climbed the steep trail to the small church atop Mount Nebo's summit. Shortly after, an organised monastic community walled off from secular society was established (Piccirillo \& Alliata 1998). A mosaic inscription at the site refers to an abbot, Alexis, leading the monastery by the late fourth century, indicating that the transition to communal living swiftly followed Egeria's visit (Piccirillo \& Alliata 1998).

Numerous pilgrims followed in Egeria's footsteps, including Peter the Iberian and his companion John Rufus (c. AD 430 and 477), and later, the Piacenza Pilgrim (c. AD 570) (Wilkinson 2002). The writings of these visitors described a thriving 'lofty' church surrounded by monasteries (Horn \& Phenix Jr 2008). Around this time, a one-room chapel was dedicated by a mosaic inscription to the community leader, Robebus (c. AD 530), to

(C) Antiquity Publications Ltd, 2019 
Margaret Judd et al.

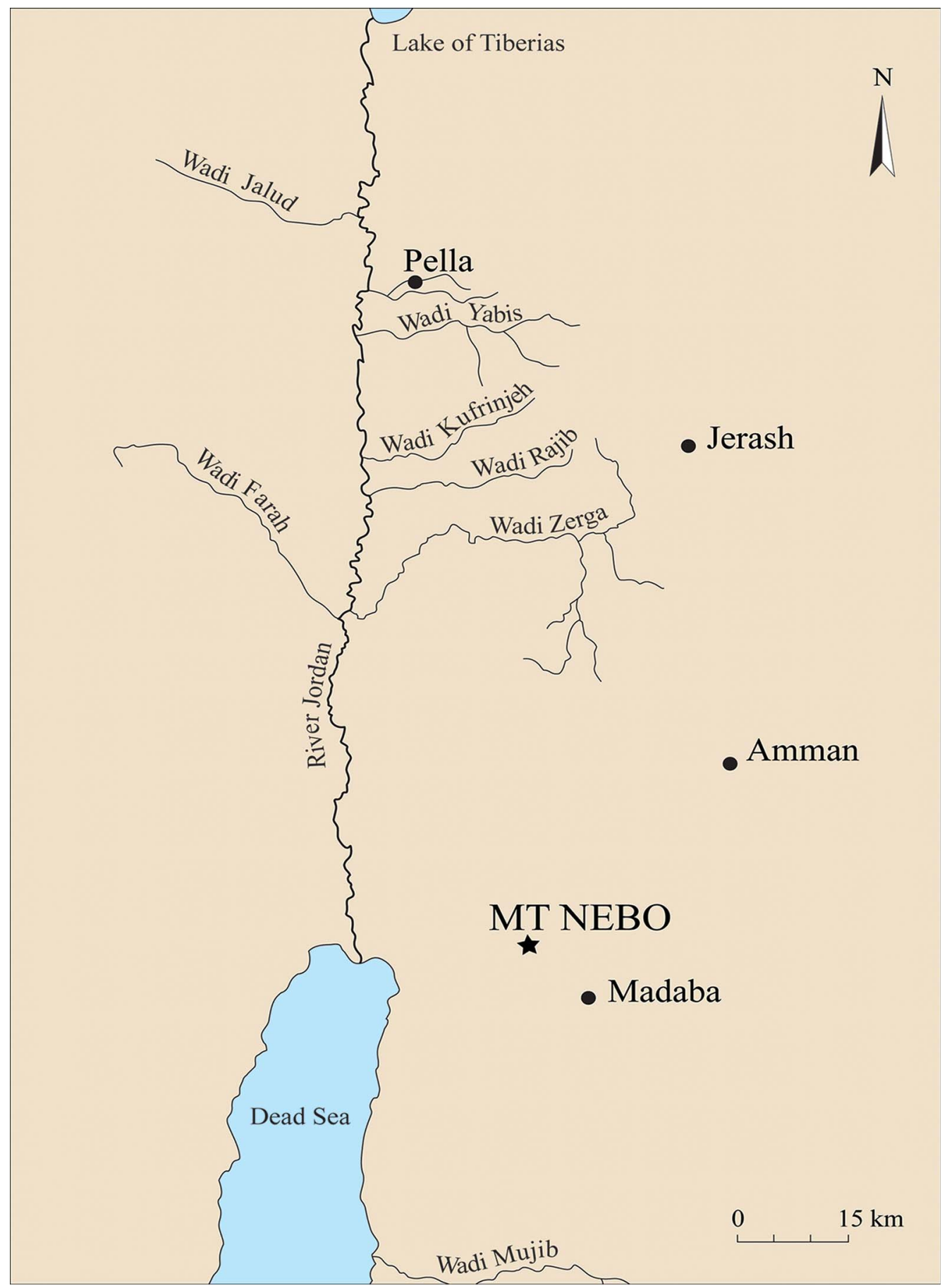

Figure 1. Map of Jordan showing the location of Mount Nebo.

(C) Antiquity Publications Ltd, 2019 


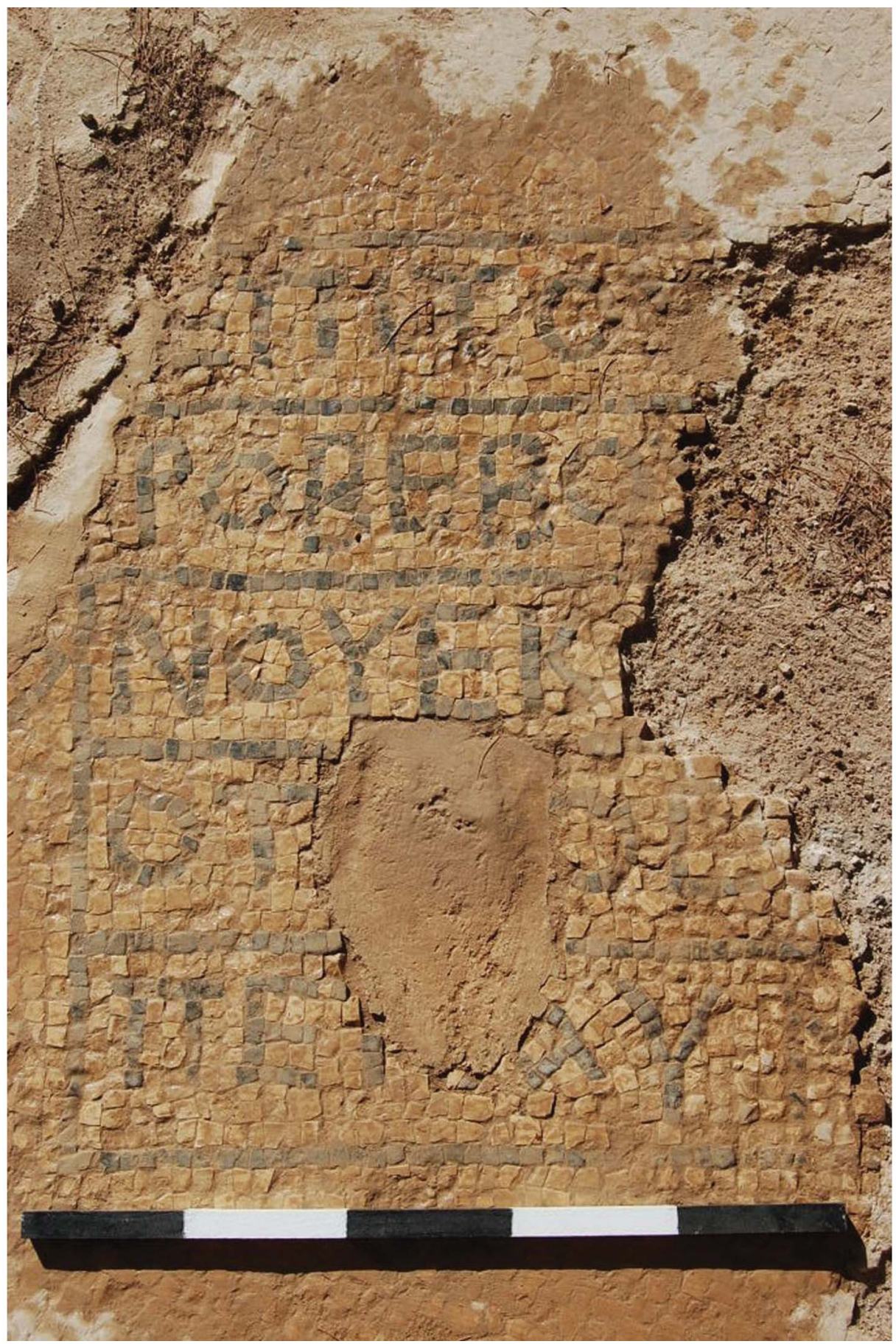

Figure 2. Mosaic inscription dedicating the Robebus Chapel to the hegumen Robebus. The text reads: In the days of the most God-fearing priest and hegumen Robebus, the [tomb of the priests] who are resting [among the saints] was built [from the foundations?] (Piccirillo \& Alliata 1998) (photograph by M. Judd).

(C) Antiquity Publications Ltd, 2019 
serve as a tomb for the priests (Piccirillo \& Alliata 1998) (Figure 2). There is no further textual information on the monastery until AD 1217, with only a brief mention by the German pilgrim Thietmar, who was en route from Acre in Israel to the Monastery of St Catherine in Sinai (Piccirillo \& Alliata 1998). Excavation and survey at Mount Nebo began in the 1930s by the Studium Biblicum Franciscanum (Saller 1941) and recommenced in 1976 under the directorship of Father Michele Piccirillo with the Institute of Franciscan Archaeology (Piccirillo \& Alliata 1998).

\section{Materials and methods}

\section{Dating and demographic analysis}

From 2007-2010, commingled skeletal remains were excavated from the north (EN) and south (ES) chambers of Mount Nebo's east crypt (Judd 2008, 2009b, 2010) (Figures 3-4). Radiocarbon dating of bone and enamel was attempted by two laboratories (Beta Analytic and University of Arizona), but was unsuccessful due to poor collagen preservation. Other means of dating, however, were available. These placed the tomb's contents between the time of Egeria's visit and the Robebus chapel dedicatory inscription (i.e. c. AD 400-530). Radiocarbon dating using IntCal13 calibration curve (Bronk Ramsey 2009; Reimer $e t$ al. 2013) of leather sandals from the crypt provides dates of 1380 \pm 30 BP (Beta-386282: cal

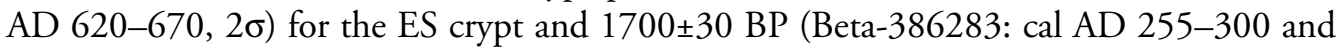
cal AD 315-405, 2 $\sigma$ ) for the EN crypt. In addition, Roman coins recovered from the crypt include one minted $c$. AD 383-402, which circulated until the sixth century (E. Alliata, pers. comm.).

The minimum number of individuals (MNI) was determined from the most frequently occurring bone element. Biological sex was estimated from dimorphic pelvic (ventral arc, subpubic concavity, ischiopubic ramus, sciatic notch and preauricular sulcus) and skull (nuchal crest, mastoid process, supra-orbital margin and ridge, mental eminence and zygomatic extension) features (Buikstra \& Ubelaker 1994; Rogers 2005). Adult age was estimated from modification to the pubic symphyseal face (Brooks \& Suchey 1990) and auricular surface (Lovejoy et al. 1985); aged individuals were assigned to broad age groups, modified slightly from the Buikstra and Ubelaker (1994) protocol.

\section{Isotopic analysis}

Strontium $\left({ }^{87} \mathrm{Sr} /{ }^{86} \mathrm{Sr}\right)$ isotope ratios are largely dependent on the ages and types of minerals present in bedrock across a given area, which differ regionally in rubidium $(\mathrm{Rb})$ abundance (radioactive ${ }^{87} \mathrm{Rb}$ isotopes decay into ${ }^{87} \mathrm{Sr}$ ) due to their unique geological histories (Ericson 1985; Bentley 2006). Correspondingly, different regions possess distinctive ${ }^{87} \mathrm{Sr} /{ }^{86} \mathrm{Sr}$ ratios that are incorporated into human skeletal tissues during the consumption of local foods, enabling bioarchaeologists to evaluate residential mobility among past people. Further information on Levantine geological zones and associated local strontium isotope ratios can be found in Shewan (2004), Perry et al. (2008, 2011) and Gregoricka and Sheridan (2017).

Stable oxygen $\left(\delta^{18} \mathrm{O}\right)$ isotope values can also be regionally distinct and are thus also utilised to identify the presence of migrants (White et al. 1998). Human $\delta^{18} \mathrm{O}$ values are (C) Antiquity Publications Ltd, 2019 


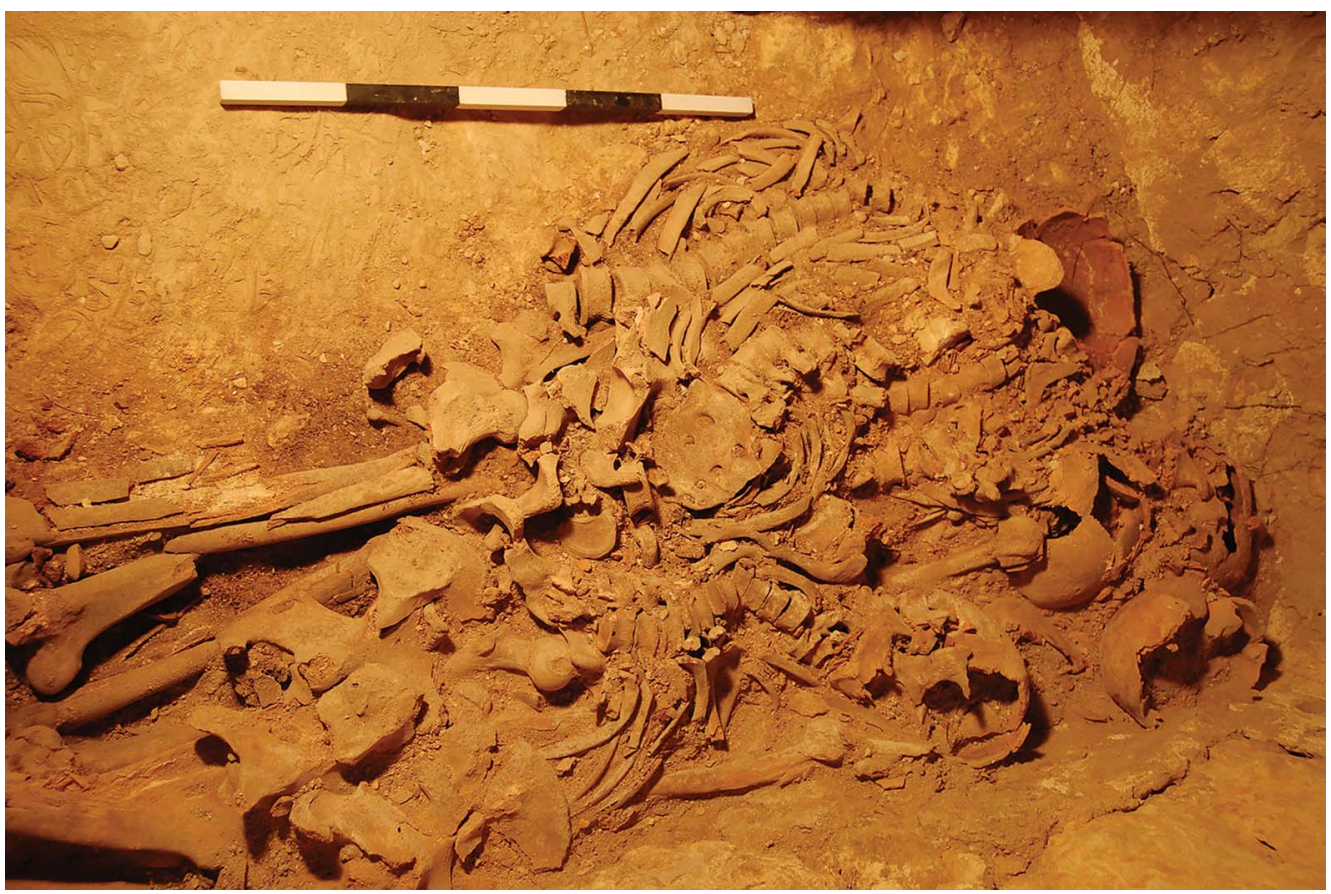

Figure 3. Early interments in the EN chamber (photograph by M. Judd).

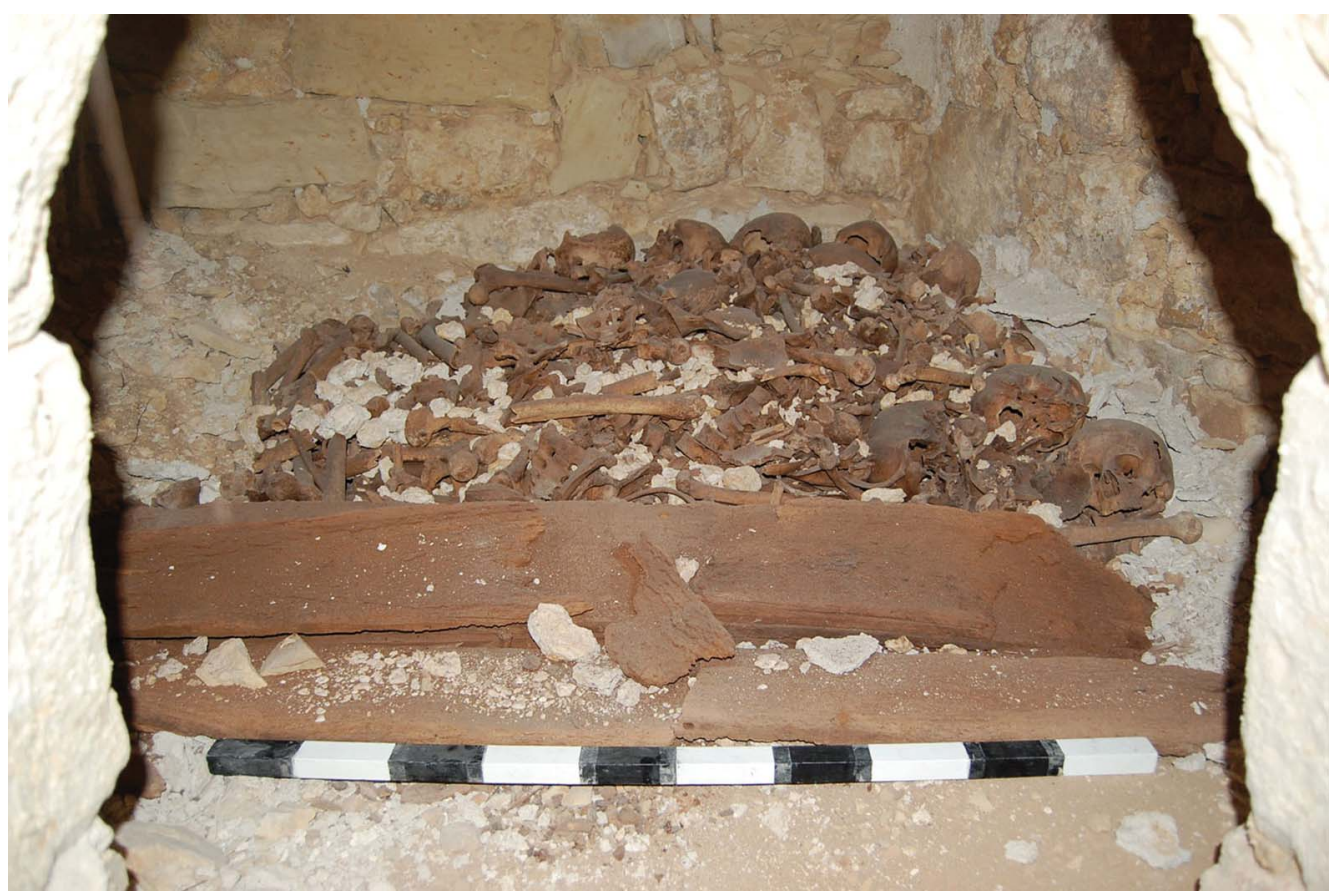

Figure 4. The ES chamber, pre-excavation (photograph by M. Judd).

(C) Antiquity Publications Ltd, 2019 
primarily derived from local sources of drinking water, representing an amalgamation of geographically specific environmental factors, including temperature, altitude and distance from the sea (Luz et al. 1984). Stable carbon $\left(\delta^{13} \mathrm{C}\right)$ isotope values distinguish between the consumption of different plant types (temperate $\mathrm{C}_{3}$ plants depleted in ${ }^{13} \mathrm{C}$ isotopes produce lower $\delta^{13} \mathrm{C}$ values vs the elevated values of tropical $\mathrm{C}_{4}$ plants) and/or terrestrial vs marine resources (Schoeninger \& Moore 1992). As people in different regions probably consumed different foods, migrants to a region may display $\delta^{13} \mathrm{C}$ values distinct from those consuming a local diet (Gregoricka \& Sheridan 2017).

Human dental enamel from ES $(n=11)$ and EN $(n=4)$ was sampled for isotopic analysis. Crown enamel of mandibular second premolars $\left(\mathrm{P}_{2}\right)(\mathrm{n}=12)$ forms between 2.5 and 7.5 years of age, while the maxillary canine $(C)$ crown $(n=3)$ begins to form as early as 7.5 months to around 6.5 years of age (Al-Qahtani et al. 2010). Isotope values from the three canines sampled here will therefore partially reflect signatures obtained from the mother for the duration of breastfeeding and weaning. Given that more ${ }^{18} \mathrm{O}$ than ${ }^{16} \mathrm{O}$ isotopes enter into body water as breast milk is consumed, the $\delta^{18} \mathrm{O}$ values of children will be elevated by around $0.5-0.7 \%$ for that period (Wright $\&$ Schwarcz 1998); these elevated values will be averaged against the direct consumption of local sources of drinking water for all postbreastfeeding years, up to 6.5 years old. As intra-site local oxygen isotope values may vary by up to 3\%o (Lightfoot \& O'Connell 2016), measures of residential mobility and geographic origins should not, however, be radically altered by breast milk. Nevertheless, oxygen isotope values from canine teeth $(n=3)$ were corrected by $0.7 \%$ o to examine the potential effects of fractionation associated with breastfeeding.

Due to limited numbers of fauna with dental enamel, bone and enamel strontium isotope ratios from archaeological rodents $(\mathrm{n}=8)$ were used to estimate local isotope bioavailability in the area surrounding Mount Nebo. Isotope local ranges were determined by statistical methods using human isotope values (Wright 2005; Knudson \& Tung 2011; Lightfoot \& O'Connell 2016), as well as Byzantine faunal values from elsewhere in the Levant. Statistical analyses comparing isotope values between two chambers were not possible given the small sample size of less than five individuals for chamber EN $(n=4)$.

Samples were analysed for strontium isotope ratios at the UNC-Chapel Hill Isotope Geochemistry Laboratory, following protocol from Perry et al. (2008). Enamel (3-5mg) was extracted from each tooth using a carbide drill bit attached to a Dremel tool, then dissolved in $3.5 \mathrm{M} \mathrm{HNO}_{3}$ before strontium isolation via column chromatography using EiChrom Sr-Spec resin. $0.1 \mathrm{M} \mathrm{H}_{3} \mathrm{PO}_{4}$ was added to resultant solutions before samples were evaporated, re-dissolved in $\mathrm{TaCl}_{5}$ and dried down prior to analysis on a VG Micromass Sector 54 thermal ionisation mass spectrometer in quintuple-collector dynamic mode. To correct for mass fractionation, an internal ratio of 0.1194 was utilised, while data are relative to $0.710250 \pm$ $0.000012(2 \sigma)$ for NBS 987. Internal precision for each analysis is generally \pm 0.000012 $0.000018(2 \sigma)$ standard error based on 100 dynamic cycles of data collection.

For stable oxygen and carbon isotopic analysis-completed at the University of Notre Dame's Center for Environmental Science and Technology_preparation of enamel carbonate followed Garvie-Lok et al. (2004). Samples were soaked for 13 hours in 2 per cent $\mathrm{NaOCl}$ and then rinsed to neutrality before a four-hour treatment with $0.1 \mathrm{M}$ acetic acid and subsequent rinse. Samples were then lyophilised using a Thermo Finnigan DeltaPlus

(C) Antiquity Publications Ltd, 2019 
Table 1. Sites with monastic structures in the Mount Nebo vicinity.

\begin{tabular}{|c|c|c|}
\hline Site & Structures & $\begin{array}{c}\text { Miles from Mount } \\
\text { Nebo }\end{array}$ \\
\hline 'Uyun Musa & $\begin{array}{l}\text { Church of Kaianus, Church of the Deacon } \\
\text { Thomas }\end{array}$ & 2.0 \\
\hline Khirbat al-Mukhayyat & Church of St George & 3.0 \\
\hline 'Ayn al-Kanisah & Monastery of the Theotokos & 4.4 \\
\hline Wadi 'Afrit & Monastery of al-Kanisah & 5.0 \\
\hline Madaba & Church of the Apostles & 5.7 \\
\hline Ma'in & Church of al-Dayr & 8.8 \\
\hline 'Ayn Qattara & Monastery at 'Ayn Qattara & 15.6 \\
\hline $\begin{array}{l}\text { Bethany beyond } \\
\text { Jordan }\end{array}$ & Monastic complex on Tell el-Kharrar & 17.8 \\
\hline Mekawer & North \& West Churches & 19.2 \\
\hline Al-Quwaysmah & Lower Church & 19.5 \\
\hline Umm al-Rasas & Tower Church complex and stylite tower & 24.5 \\
\hline
\end{tabular}

V IRMS coupled with a Gasbench II. Under vacuum, samples were acidified with 100 per cent ortho-phosphoric acid, cryogenically purified and normalised using NBS-19. Standard deviations of repeated measures of an internal standard included $\pm 0.05 \%$ for $\delta^{18} \mathrm{O}$ and $\pm 0.04 \%$ for $\delta^{13} \mathrm{C}$.

\section{Epigraphic, onomastic and architectural analysis}

Mosaic inscriptions $(n=44)$ recorded by the original excavators of the Mount Nebo region (Saller 1941; Piccirillo \& Alliata 1998) were assessed for onomastic and epigraphic evidence of non-local influence. These inscriptions were considered within the context of historical documents and diaries. Pilgrim records of times and distances travelled between staging posts and towns indicate that the average distance travelled in a day was 19 miles, although staging posts ranged from 15-29 miles apart (Wilkinson 2002). Eleven monastic structures within an approximately 50-mile radius (an overnight journey) from Mount Nebo, and bounded to the west by the Jordan River, were evaluated for non-local architectural influences (Table 1).

\section{Results and discussion}

\section{Demography}

The adult MNI for the EN group was 26 (based on left hamate and femur presence), while the ES MNI produced 47 adults (based on the presence of the right capitate, talus and patella). Although dimorphic cranial features were ambiguous in some cases, no skull was assessed as definitely female. Male dimorphic features predominated the pelvic bones, with one exception (skeleton 30B), which had an unusually deep preauricular sulcus. This alone, however, is a weak predictor of biological sex. Modification of the left auricular surface 
Table 2. Demography of aged youths and adults.

\begin{tabular}{lcc}
\hline Age range (years) & EN & ES \\
\hline $15-18$ & 1 & 0 \\
$18-25$ & 0 & 4 \\
$25-35$ & 2 & 19 \\
$35-50$ & 3 & $16^{*}$ \\
$50+$ & 1 & 0 \\
Total & $7 / 26(27 \%)$ & $39 / 47(83 \%)$ \\
\hline
\end{tabular}

* One possible female.

was the most frequently preserved age-related feature. Even so, age could be estimated for only 46 of 73 individuals (Table 2). Adult membership in the two crypts was restricted to males, with the possible exception of skeleton 30B.

Although pilgrims spoke only of males at Mount Nebo, female monastics resided elsewhere; some females were known to disguise themselves as males in order to gain membership into religious communities, and were only exposed at death (Davis 2002; Dietz 2005; Horn \& Phenix Jr 2008). Among comparative Judean monasteries, human skeletal remains were assessed as entirely male at Khan el-Ahmar (Hershkovitz et al. 1993) and predominately male at St Stephen's Monastery in Jerusalem (Sheridan \& Gregoricka 2015). One adult female was recovered at Deir 'Ain 'Abata (Gruspier 2012). While one female monastic may have been present at Mount Nebo (skeleton 30B), bioarchaeological evidence elsewhere in the region has revealed very few possible female skeletons associated with monasteries.

\section{Stable isotopes}

Both strontium $($ mean $=0.70811 \pm 0.00032,1 \sigma)$ and oxygen $($ mean $=-1.3 \pm 2.6 \%$, $1 \sigma)$ isotope values exhibit considerable variability, with numerous outliers suggestive of the presence of multiple individuals who grew up in areas geologically and/or hydrologically distinct from that surrounding Mount Nebo (Table 3 \& Figure 5). For both crypts, only three individuals fell within the narrow confines of locally bioavailable ${ }^{87} \mathrm{Sr} /{ }^{86} \mathrm{Sr}$ ratios, as defined by contemporaneous rodents from shared archaeological contexts $(0.70815 \pm 0.00002,2 \sigma$; Table 4). Archaeological faunal ${ }^{87} \mathrm{Sr} /{ }^{86} \mathrm{Sr}$ ratios measured elsewhere in the Jordanian Highlands, however, range from $0.70815-0.70834$ (Perry et al. 2008). This, coupled with two human individuals (L64 and L93) whose $\delta^{18} \mathrm{O}_{\mathrm{c}(\mathrm{VPDB})}$ and $\delta^{13} \mathrm{C}_{\mathrm{ap}}$ (VPDB) values fell well outside of apparent local value clusters, indicates that at least seven of those interred in the EN $(n=1)$ and ES $(n=6)$ chambers may have spent their childhoods outside the region. The high $\delta^{18} \mathrm{O}_{\mathrm{c}(\mathrm{VPDB})}$ values for L64 and L93 were similar to those observed in South-eastern Arabia (e.g. Gregoricka 2011; Schrenk et al. 2016), hinting at possible Arabian origins.

As fauna cannot be used to determine local oxygen isotope bioavailability, values from meteoric water may provide evidence for regional isotopic differences in water sources

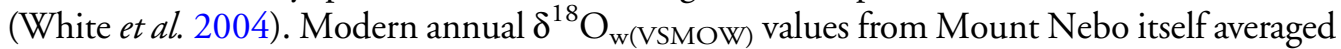
$-5.8 \pm 0.1 \%$, similar to nearby Madaba $(-5.8 \pm 0.1 \%$ ), Amman $(-6.2 \pm 0.1 \%$ ) and Jerusalem $(-6.0 \pm 0.1 \%$ ) (Bowen \& Revenaugh 2003; IAEA/WMO 2015; Bowen 2018). When converted to $\delta^{18} \mathrm{O}_{\mathrm{c}(\mathrm{VPDB})}$ values, these range in mean between -4.1 to $-3.9 \%$ (Coplen (C) Antiquity Publications Ltd, 2019 
Table 3. Strontium, oxygen and carbon isotope values at Mount Nebo, Jordan. Bolded text represents values designated as non-local based on associated fauna and/or statistical analyses.

\begin{tabular}{lllccc}
\hline Chamber & Specimen ID & Tooth & ${ }^{\mathbf{8}} \mathrm{Sr} /{ }^{86} \mathrm{Sr}$ & $\delta^{\mathbf{1 8}} \mathrm{O}_{\mathrm{c} \text { (VPDB) }}$ & $\delta^{\mathbf{1 3}} \mathrm{C}_{\mathrm{ap} \text { (VPDB) }}$ \\
\hline $\mathrm{EN}$ & Skull 3 & $\mathrm{RP}_{2}$ & 0.708212 & -1.1 & -11.7 \\
$\mathrm{EN}$ & Skull 2 & $\mathrm{R}^{\mathrm{c}}$ & 0.708201 & $-0.4(-1.1)$ & -11.8 \\
$\mathrm{EN}$ & Skull 12 & $\mathrm{R}^{\mathrm{c}}$ & $\mathbf{0 . 7 0 8 5 0 1}$ & $-3.1(-3.8)$ & -11.0 \\
$\mathrm{EN}$ & Skull 9 & $\mathrm{R}^{\mathrm{c}}$ & 0.708157 & $-1.7(-2.4)$ & -11.3 \\
$\mathrm{ES}$ & Locus 5 east & $\mathrm{RP}_{2}$ & $\mathbf{0 . 7 0 7 3 6 0}$ & $\mathbf{- 4 . 4}$ & $\mathbf{- 1 0 . 4}$ \\
$\mathrm{ES}$ & Near skeleton 98 & $\mathrm{RP}_{2}$ & 0.708253 & -3.5 & -12.5 \\
$\mathrm{ES}$ & Locus 52 & $\mathrm{RP}_{2}$ & $\mathbf{0 . 7 0 8 0 6 6}$ & -0.1 & -11.7 \\
$\mathrm{ES}$ & Locus 52 & $\mathrm{RP}_{2}$ & $\mathbf{0 . 7 0 7 3 9 7}$ & -3.9 & $\mathbf{- 1 0 . 7}$ \\
$\mathrm{ES}$ & Locus 29 & $\mathrm{RP}_{2}$ & 0.708175 & -2.5 & -12.3 \\
$\mathrm{ES}$ & Skull 87A & $\mathrm{RP}_{2}$ & 0.708202 & -1.9 & -11.6 \\
$\mathrm{ES}$ & Locus 93 & $\mathrm{RP}_{2}$ & 0.708171 & $\mathbf{+ 4 . 6}$ & $\mathbf{- 1 4 . 7}$ \\
$\mathrm{ES}$ & Locus 14 & $\mathrm{RP}_{2}$ & $\mathbf{0 . 7 0 8 4 1 6}$ & -0.6 & -12.5 \\
$\mathrm{ES}$ & Locus 11 & $\mathrm{RP}_{2}$ & 0.708188 & -2.8 & -11.8 \\
$\mathrm{ES}$ & Locus 87 & $\mathrm{RP}_{2}$ & 0.708196 & -1.5 & -11.6 \\
$\mathrm{ES}$ & Locus 64 & $\mathrm{RP}_{2}$ & 0.708159 & $\mathbf{+ 3 . 8}$ & $\mathbf{- 1 4 . 0}$ \\
\hline
\end{tabular}

$\mathrm{R}^{\mathrm{c}}=$ right upper canine; $\mathrm{RP}_{2}=$ right lower premolar; oxygen isotope values in parentheses reflect values corrected by $-0.7 \%$ for breastfeeding in canine teeth sampled.

et al. 1983; Chenery et al. 2012), considerably different from average $\delta^{18} \mathrm{O}_{\mathrm{c}(\mathrm{VPDB})}$ values $(-1.3 \pm 2.6 \%$ o $1 \sigma)$ produced at Mount Nebo. This may in part suggest that modern precipitation values in this region have been altered too dramatically by temporal changes in climate to apply to studies of Byzantine regional mobility. Average human oxygen isotope values at Mount Nebo may not, however, be wholly representative of local regional values, due to the large number of apparent migrants to the region, whose non-local values skew actual local averages, making a comparison between human and precipitation values tenuous. Researchers working elsewhere advocate the use of trimmed datasets comprised of intra-site human values (Wright 2005; Knudson \& Tung 2011); once outliers are removed, these result in expected local ranges (mean $\pm 2 \mathrm{SD}$ ) of $0.70814-0.70826$ for strontium, -3.9 to $+0.1 \%$ o for oxygen, and -12.6 to $-11.0 \%$ for carbon isotopes. Taken together, these ranges classify the same seven Mount Nebo individuals, who previously were designated as non-local by faunal values, as outliers, in addition to a visual assessment of outliers on the scatterplot. These values nearly encompass the oxygen isotope data $(-2.8$ to $+0.2 \%$ ) reported for 30 individuals from Byzantine Khirbet Faynan in south-western Jordan (Perry et al. 2011), and are similar to mean enamel values produced by 43 individuals at Late Bronze Age/

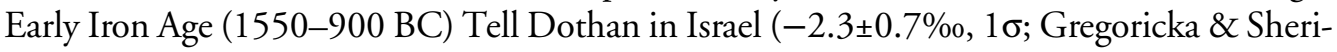
dan 2017).

Enamel from human canine teeth (which form in part during breastfeeding) all demonstrated local oxygen isotope values, even after the application of a $0.7 \%$ correction (Table 3 ). This reaffirms initial interpretations, resulting in only a slight change in mean $(-1.4 \pm 2.6 \%$, $1 \sigma)$ and no change in standard deviation. Interestingly, the adjusted value $(-3.8 \%$ ) from 


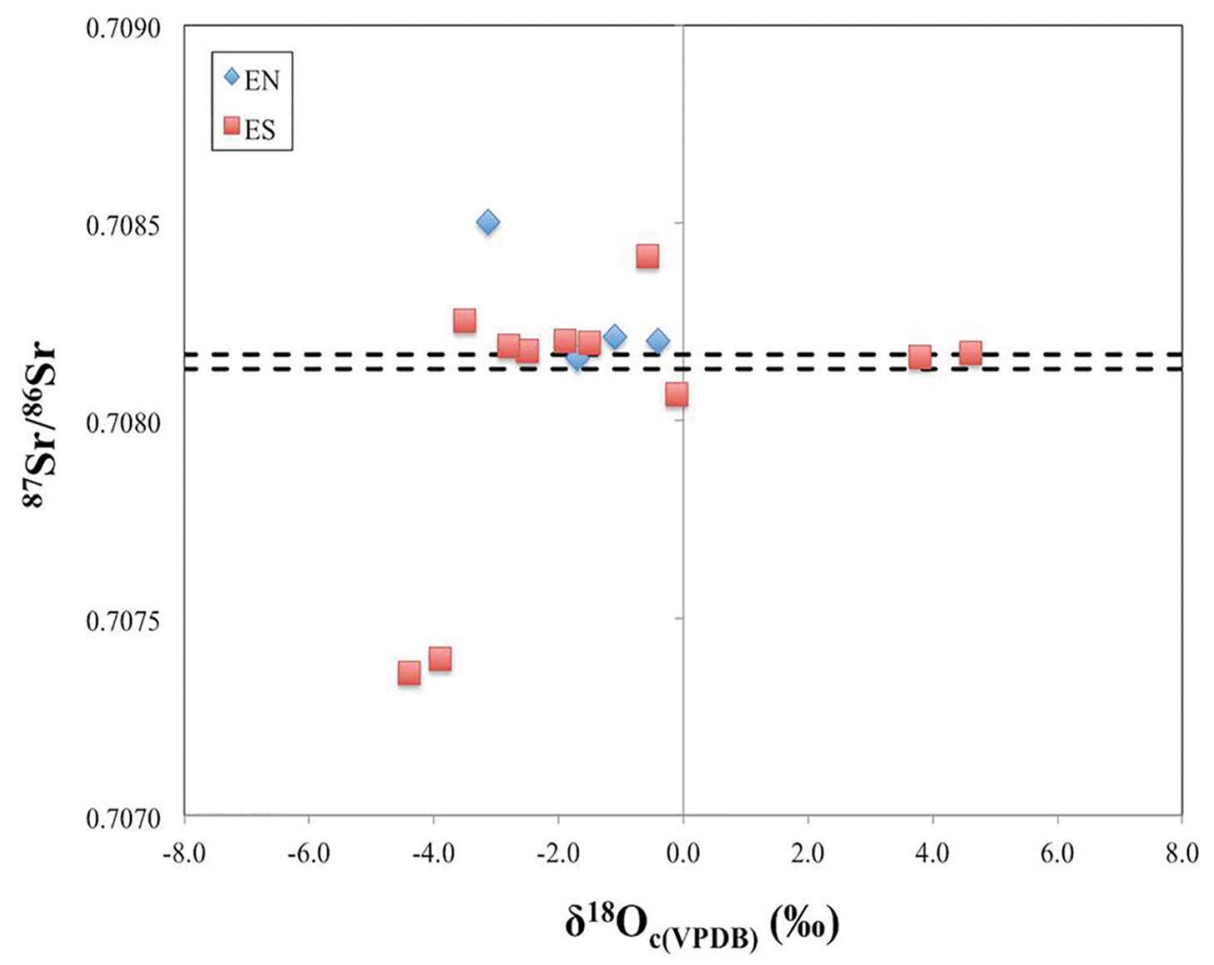

Figure 5. Radiogenic strontium and stable oxygen isotope values from human dental enamel for individuals interred in the EN and ES chambers at Mount Nebo. The space between the dotted lines represents strontium values local to the area, based on archaeological fauna.

individual EN skull 12 now more closely approaches the lower limit $(-3.9$ to $+0.1 \%$ of of the locality, which fits with that same individual's non-local strontium ratio (0.708501).

Mean stable carbon isotope values $(-12.0 \pm 1.1 \%, 1 \sigma)$ are more tightly clustered but similarly reveal two outliers (Table 3), who in childhood consumed more ${ }^{13} \mathrm{C}$-depleted resources, while also exhibiting elevated, non-local oxygen isotope values. As with strontium, both outliers are from the ES crypt, suggesting that a person's status as a migrant to the monastery may have influenced tomb

Table 4. Rodent strontium isotope ratios at Mount Nebo, Jordan.

\begin{tabular}{lcll}
\hline Crypt & Locus & Sample & ${ }^{87} \mathrm{Sr} /{ }^{86} \mathrm{Sr}$ \\
\hline EN & 2 & Bone & 0.708147 \\
ES & 10 & Bone & 0.708154 \\
ES & 6 & Bone & 0.708150 \\
ES & 4 & Bone & 0.708144 \\
ES & 50 & Enamel & 0.708136 \\
ES & 41 & Enamel & 0.708165 \\
ES & 2 & Enamel & 0.708148 \\
ES & 62 & Enamel & 0.708138 \\
\hline
\end{tabular}

(C) Antiquity Publications Ltd, 2019 
membership; the majority of non-locals (88 per cent) originated from the ES chamber. After excluding these two outliers (producing a revised average of $-11.6 \pm 0.6 \% 0,1 \sigma$ ), all other individuals appear to have also consumed a diet primarily comprised of $\mathrm{C}_{3}$ resources - albeit with some $\mathrm{C}_{4}$ contributions. These values are similar to those exhibited by the Bronze Age inhabitants of Ya'amoun in northern Jordan $($ mean $=-11.9 \%$ ) (Al-Shorman 2004). While domesticated fauna from Mount Nebo were not available for evaluating local trophic levels directly, $\delta^{13} \mathrm{C}_{\mathrm{co}}$ values from three different sites in Byzantine Jerusalem confirm a heavy reliance on $\mathrm{C}_{3}$ resources (Gregoricka \& Sheridan 2013).

\section{Epigraphy, onomastics and architecture}

St Anthony founded the first anchorite monastic community in the Egyptian desert in the late third century AD. This was followed by cenobitic organisations in the Desert of Sketis, south of Alexandria, in the mid fourth century (Meinardus 1992). Egyptian monks were forced to flee from Egypt in the early fifth century, and, according to Peter the Iberian,

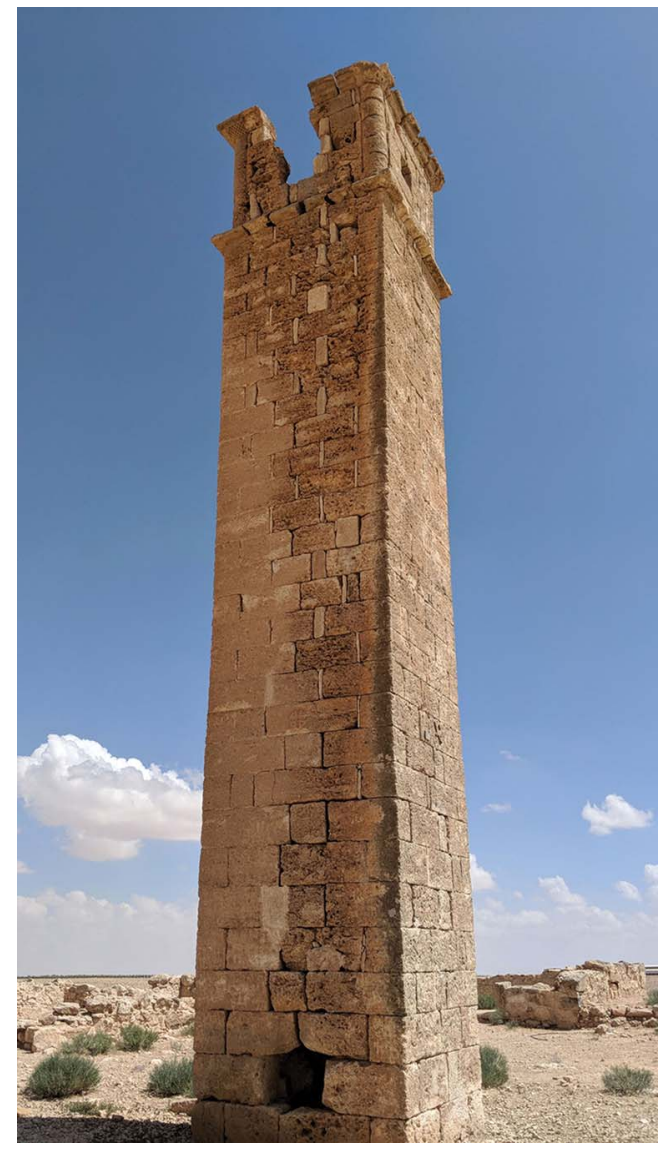

Figure 6. Stylite tower at Umm al-Rasas (photograph by D. Foran). some settled at Mount Nebo, establishing an Egyptian monastic presence in this area (Medebielle 1987; Wilkinson 2002). In addition to Peter's account, evidence for Egyptian monastics appears in an Aramaic inscription at al-Quwaysmah (c. 717/18 $\mathrm{AD})$. The name 'bd-Raytou probably refers to a monk who served at the monastery of Raytou on the Sinai coast (Piccirillo 1984). The monastic movement in northern Syria also influenced the communities at Mount Nebo. The practice of stylitism, for example, which emerged in northern Syria in the early fifth century and was largely confined to this region, can be found amongst the Mount Nebo monasteries (Foran 2005b). Architectural evidence for stylite towers at 'Ayn al-Kanisah and Umm al-Rasas (Figure 6), as well as a mosaic inscription from 'Ayn al-Kanisah, indicates a northern Syrian connection (Foran 2005b).

Mosaic inscriptions provide similar direct evidence for cultural diversity among the first monks and clerics of the region. An Aramaic floor inscription at the Church of Kaianus at Uyun Musa (late fifth to early sixth centuries $\mathrm{AD}$ ) is the earliest example of this script in Transjordan (Figure 7)

(C) Antiquity Publications Ltd, 2019 


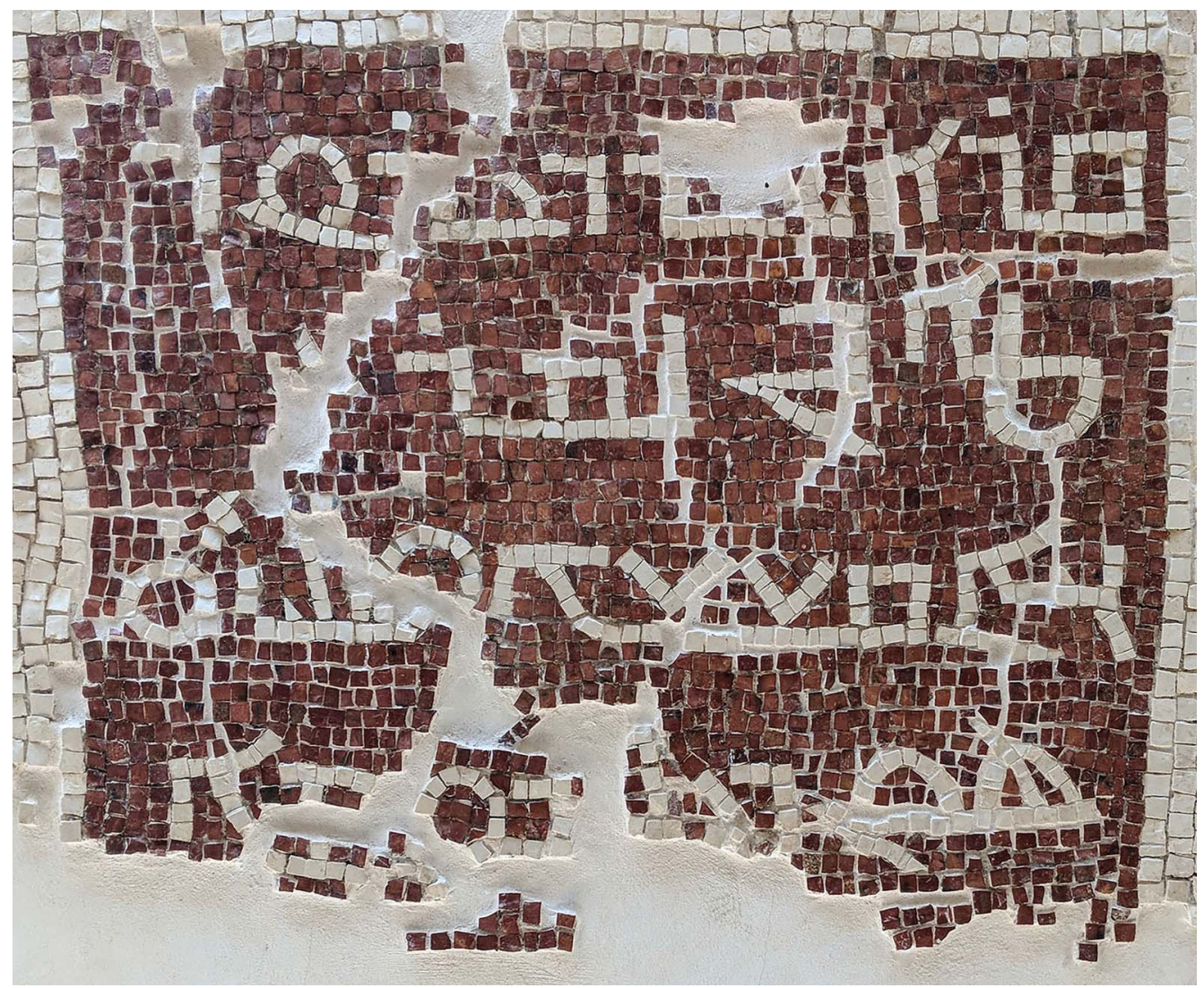

Figure 7. Mosaic inscription from the Lower Church of Kaianus. The text reads: The lector will remember the good works of our lord, Gayyân the priest (or son of) Kasiseus, and the heirs who made (or restored) the furnishings (or parts) of ... (Piccirillo \& Alliata 1998) (photograph by D. Foran).

(DiSegni 1998). The priest Gayyân mentioned in this text, may be the mid fifth-century AD Bishop of Madaba, referred to by Cyril of Scythopolis in the Life of St Euthymius (Price \& Binns 1991). The Bishop of Madaba mentioned in the records of the Council of Chalcedon — recorded approximately six years before these events — was named Gaianus (Medebielle 1987); similarly, according to the Life of St Euthymius, there was a Gaianus from the same city as Euthymius - namely Melitene (modern Malatya), in central Anatolia. If the priest Gayyân mentioned in the Church of Kaianus mosaic is indeed Gaianus, the firstknown Bishop of Madaba, it not only indicates a connection between the Christian communities of central Anatolia and Transjordan, but also an important link between the monastic communities of the Judean Desert and those of the Nebo region.

Moreover, the names of the monks at Mount Nebo may indicate regional origins and can thus be indicative of diverse geographic and cultural backgrounds. Of the 44 inscriptions found on dedicatory mosaics naming monastics at Mount Nebo, most have either a Semitic (39 per cent) or a Greek (48 per cent) root (Figure 8); only a few (7 per cent) have Latin names, such as Longinus (Foran 2005a). The names of Semitic origin range from well (C) Antiquity Publications Ltd, 2019 


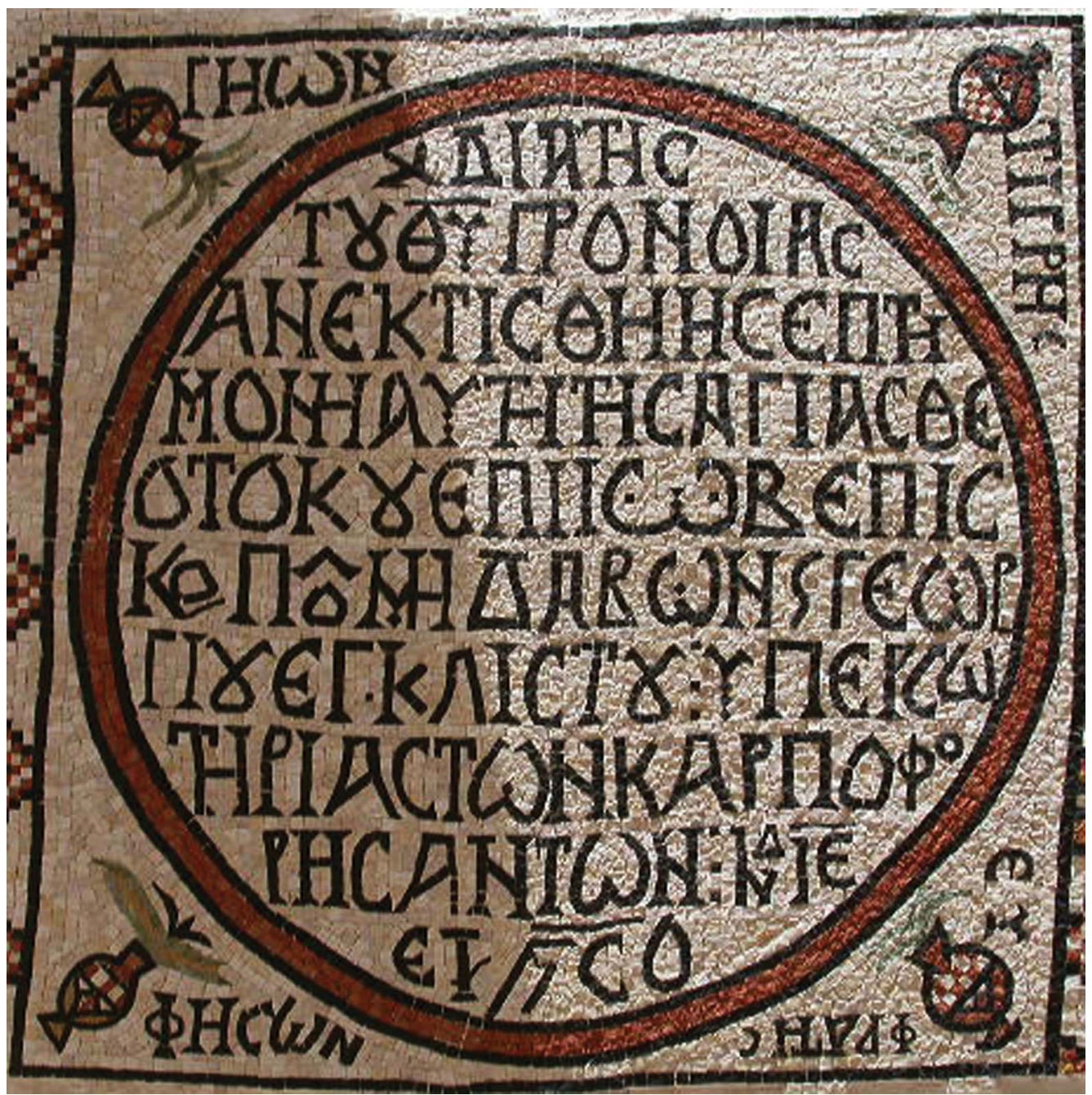

Figure 8. The dedicatory inscription from the Chapel of the Theotokos at Ayn al-Kanisah lists two names, Job (Semitic) and George (Greek). The text reads: By the providence of God this venerable monastery of the holy Mother of God (Theotokos) was rebuilt, in the days of Job, bishop of Madaba, and of George the recluse, for the preservation of all the benefactors, indiction 15, year 6270 [762 AD] (Piccirillo \& Alliata 1998) (photograph by D. Foran).

known to unique. Kasiseus, for example, is an Arabic name that appears frequently in the Nebo region, but is rare elsewhere. The name Robebus/Rabebus is also particular to this area, the most notable reference being the dedicatory mosaic of the Robebus Chapel (Figure 2). Many Greek names, such as John, are common, while Alexis-one of the first abbots at Mount Nebo-is rare and does not appear in any other inscription in Palestine. The name Procapis is unusual in that it is an abbreviated version of Procopius, a Caesarean martyr saint.

Onomastic evidence for geographic origins is, nevertheless, problematic, as foreigners often adopted popular local names in honour of their new community; conversely, local monastics might have assumed non-local names in honour of a famous person or saint (Foran 2005a).

(C) Antiquity Publications Ltd, 2019 
Furthermore, due to iconoclastic damage, not all names are preserved. The complete absence of feminine names in the Mount Nebo vicinity (Piccirillo \& Alliata 1998) may be due to issues of preservation, females adopting male names, or simply the absence of female monastics.

\section{Conclusion}

Mount Nebo remains a popular pilgrimage destination today due to its historical and spiritual association with the Prophet Moses (Orekat 2016). In the Byzantine period, it also functioned as a crossroads for travellers, traders and pilgrims, connecting surrounding polities of the Old World. Biological and archaeological evidence supports a monastic ethnic 'mosaic' at Mount Nebo. Overall isotopic variability suggests that approximately half of those sampled from Mount Nebo consumed water and foodstuffs from other geographic regions during childhood, indicating that these people arrived at Mount Nebo sometime later in life, after enamel formation was complete. Furthermore, the monasteries within the Mount Nebo network demonstrate-at varying levels in their architecture and the range of names from mosaic inscriptions - that there was a foreign presence in this region during the Byzantine period. Although the funerary practices of the monastic community obscured the identity of individuals in death — as it did in life-multiple lines of evidence indicate the diverse ethnic and geographic origins of those who lived and died at Mount Nebo.

\section{Acknowledgements}

We would like to thank the Department of Antiquities of Jordan (Madaba and Amman); the Franciscan Institute of Archaeology, including Fathers Piccirillo, Pappalardo, Alliata, Fergus and Rami; Franco Sciorilli; Akmed el-Wukhyan and family; American Center of Oriental Research; University of Pittsburgh CRDF and A\&S Small Grants (PI: M.A. Judd); and The Wenner-Gren Foundation (\#38029, PI M.A. Judd).

\section{References}

Al-QAhtani, S.J., M.P. Hector \& H.M. LIVERSIDGE. 2010. Brief communication: the London atlas of human tooth development and eruption. American Journal of Physical Anthropology 142: 481-90. https://doi.org/10.1002/ajpa.21258

AL-Shorman, A. 2004. Stable carbon isotope analysis of human tooth enamel from the Bronze Age cemetery of Ya'amoun in northern Jordan. Journal of Archaeological Science 31: 1693-98.

https://doi.org/10.1016/j.jas.2004.05.002

Avi-Yonah, M. 1954. The Madaba map. Jerusalem: Israel Exploration Society.

Bentley, R. 2006. Strontium isotopes from the earth to the archaeological skeleton: a review. Journal of Archaeological Method and Theory 13: 135-87.

https://doi.org/10.1007/s10816-006-9009-x
Bowen, G.J. 2018. The online isotopes in precipitation calculator, version OIPC2.2. University of Utah. Available at http://www.waterisotopes.org (accessed 23 January 2019).

Bowen, G.J. \& J. Revenaugh. 2003. Interpolating the isotopic composition of modern meteoric precipitation. Water Resources Research 39: 1299. https://doi.org/10.1029/2003WR002086

Bronk Ramsey, C. 2009. Bayesian analysis of radiocarbon dates. Radiocarbon 51: 337-60. https://doi.org/10.1017/S0033822200033865

Brooks, S. \& J.M. Suchey. 1990. Skeletal age determination based on the os pubis: a comparison of the Acsádi-Nemeskéri and Suchey-Brooks methods. Journal of Human Evolution 5: 227-38. https://doi.org/10.1007/BF02437238

Buikstra, J.E. \& D.H. Ubelaker. 1994. Standards for data collection from human skeletal remains. Proceedings of a seminar at the Field Museum of

(C) Antiquity Publications Ltd, 2019 
Natural History organized by Jonathan Haas (Arkansas Archaeological Survey Research Series 44). Fayetteville: Arkanas Archaeological Survey.

Chenery, C., V. Pashley, A. Lamb, H. Sloane \& J. Evans. 2012. The oxygen isotope relationship between the phosphate and structural carbonate fractions of human bioapatite. Rapid Communications in Mass Spectrometry 26: 309-19. https://doi.org/10.1002/rcm.5331

Coplen, T., C. Kendall \& J. Hopple. 1983. Comparison of stable isotope reference samples. Nature 302: 236-38. https://doi.org/10.1038/302236a0

Davis, S. 2002. Crossed texts, crossed sex: intertextuality and gender in Early Christian legends of holy women disguised as men. Journal of Early Christian Studies 10: 1-36. https://doi.org/10.1353/earl.2002.0003

Dietz, M. 2005. Wandering monks, virgins and pilgrims: ascetic travel in the Mediterranean world. A.D. 300-800. University Park: Pennsylvania State University.

DiSEgnI, L. 1998. The Greek inscriptions, in M. Piccirillo \& E. Alliata (ed.) Mount Nebo: new archaeological excavations, 1967-1997: 425-67. Jerusalem: Studium Biblicum Franciscanum.

ERICSON, J. 1985. Strontium isotope characterization in the study of prehistoric human ecology. Journal of Human Evolution 14: 503-14.

https://doi.org/10.1016/S0047-2484(85) 80029-4

Foran, D. 2005a. The monks of the Eastern Desert: Mount Nebo and its monastic communities. Unpublished Licentiate in Mediaeval Studies, University of Toronto.

-2005 b. The Stylites of Nebo: a Syrian tradition in the highlands of central Jordan. Journal of the Canadian Society for Syriac Studies 5: 68-81.

Garvie-LoK, S., T. Varney \& M. Katzenberg. 2004. Preparation of bone carbonate for stable isotope analysis: the effects of treatment time and acid concentration. Journal of Archaeological Science 31: 763-76. https://doi.org/10.1016/j.jas.2003.10.014

Gingras, G.E. 1970. Egeria: diary of a pilgrimage. Translated by G.E. Gingras. New York: Newman.

GregoricKA, L. 2011. Mobility, exchange, and tomb membership in Bronze Age Arabia. Unpublished PhD dissertation, The Ohio State University.
Gregoricka, L. \& S. Sheridan. 2013. Ascetic or affluent? Byzantine diet at the monastic community of St. Stephen's, Jerusalem from stable carbon and nitrogen isotopes. Journal of Anthropological Archaeology 32: 63-73. https://doi.org/10.1016/j.jaa.2012.10.002

- 2017. Continuity or conquest? A multi-isotope approach to investigating identity in the Early Iron Age of the southern Levant. American Journal of Physical Anthropology 162: 73-89. https://doi.org/10.1002/ajpa.23086

Gruspier, K. 2012. The Byzantine/Ummayad human skeletal remains, in D. Politis (ed.) Excavations of the Sanctuary of Lot at Deir 'Ain 'Abata in Jordan, 1988-2003: 421-48. Amman: Jordan Distribution Agency.

Hershrovitz, I., R. Yakar, C. Taitz, S. Wish-Baratz, A. Pinhasov \& B. Ring. 1993. The human remains from the Byzantine monastery at Khan el-Ahmar. Liber Annuus 43: 373-85.

Hirschfeld, Y. 2006. The monasteries of Palestine in the Byzantine Period, in O. Limor \& G.G. Stroumsa (ed.) Christians and Christianity in the Holy Land: 401-19. Turnhout: Brepols. https://doi.org/10.1484/M.CELAMA-EB.3. 3199

Horn, C. \& R.J. Phenix JR (ed.). 2008. John Rufus: lives of Peter the Iberian, Theodosius of Jerusalem, and the Monk Romanus. Atlanta (GA): Society of Biblical Literature.

IAEA/WMO. 2015. Global network of isotopes in precipitation. The GNIP database. Available at: https://nucleus.iaea.org/wiser (accessed 23 January 2019).

JudD, M.A. 2008. The crypts at the Chapel of Robebus, Mount Nebo. Liber Annuus 57: 656-60.

- 2009a. Bioarchaeology east of Jordan, in P. Bientrowski (ed.) Studies on Iron Age Moab and neighbouring areas in honour of Michèle Daviau: 245-73. Leuven: Peeters.

- 2009b. The 2008 excavation season at the Chapel of Robebus. Liber Annuus 58: 524-28.

-2010. The 2010 excavation season at the Chapel of Robebus. Liber Annuus 60: 425-28.

King James Bible Online. 2017. The Holy Bible, King James Version. Cambridge Edition: 1769. Available at: www.kingjamesbibleonline.org (accessed 23 January 2019).

Knudson, K. \& T. Tung. 2011. Investigating regional mobility in the southern hinterland of 
the Wari empire: biogeochemistry at the site of Beringa, Peru. American Journal of Physical Anthropology 145: 299-310. https://doi.org/10.1002/ajpa.21494

Lightfoot, E. \& T. O'Connell. 2016. On the use of biomineral oxygen isotope data to identify human migrants in the archaeological record: intra-sample variation, statistical methods and geographical considerations. PLOS ONE 11: e0153850.

https://doi.org/10.1371/journal.pone.0153850

Lovejoy, C.O., R.S. Meinde, T.R. Pryzbeck \&

R.P. Mensforth. 1985. Chronological metamorphosis of the auricular surface of the ilium: a new method for the determination of adult skeletal age at death. American Journal of Physical Anthropology 68: 15-28.

https://doi.org/10.1002/ajpa.1330680103

Luz, B., Y. Kolodny \& M. Horowitz. 1984. Fractionation of oxygen isotopes between mammalian bone-phosphate and environmental drinking water. Geochimica et Cosmochimica Acta 48: 1689-93. https://doi.org/10.1016/0016-7037(84)90338-7

MacDonald, B. 2010. Pilgrimage in Early Christian Jordan. Oxford: Oxbow.

Medebielle, P. 1987. Madaba et son histoire chrétienne. Jerusalem: Imprimerie du Patriarcat Latin.

MeInardus, O.F.A. 1992. Monks and monasteries of the Egyptian deserts. Cairo: American University in Cairo Press.

Orekat, F. 2016. Understanding visitors' experiences at religious heritage sites: a case study from Jordan. Unpublished PhD dissertation, University of Sydney.

Perry, M. 2012. Paleopathology in Lebanon, Syria and Jordan, in J.E. Buikstra \& C.A. Roberts (ed.) The global history of paleopathology: pioneers and prospects: 451-69. New York: Oxford University Press. https:/doi.org/10.1093/acprof:osobl/ 9780195389807.003.0049

Perry, M., D. Coleman \& N. Delhopital. 2008. Mobility and exile at $2^{\text {nd }}$ century A.D. Khirbet edh-Dharih: strontium isotope analysis of human migration in western Jordan. Geoarchaeology 23: 528-49. https://doi.org/10.1002/gea.20230

Perry, M., D. Coleman, D. Dettman, J. Grattan \& A. Halim AL-Shiyab. 2011. Condemned to metallum? The origin and role of $4^{\text {th }}-6^{\text {th }}$ century A.D. Phaeno mining camp residents using multiple chemical techniques. Journal of Archaeological Science 38: 558-69. https://doi.org/10.1016/j.jas.2010.10.010

Piccirillo, M. 1984. Le chiese di QuweismehAmman. Liber Annuus 34: 329-40.

Piccirillo, M. \& E. Alliata. 1998. Mount Nebo: new archaeological excavations 1967-1997. Jerusalem: Studium Biblicum Franciscanum.

Price, R.M. \& J. Binns. 1991. Lives of the monks of Palestine, by Cyril of Scythopolis. Translated by R.M. Price. Kalamazoo: Cistercian Publications.

Reimer, P.J. et al. 2013. IntCal13 and Marine13 radiocarbon age calibration curves $0-50000$ years cal BP. Radiocarbon 55: 1869-87. https://doi.org/10.2458/azu_js_rc.55.16947

Rogers, T.L. 2005. Determining the sex of human remains through cranial morphology. Journal of Forensic Sciences 50: 493-500. https://doi.org/10.1520/JFS2003385

SAlLER, S.J. 1941. The memorial of Moses on Mount Nebo. Jerusalem: Franciscan.

Schoeninger, M.J. \& K. Moore. 1992. Bone stable isotope studies in archaeology. Journal of World Prehistory 6: 247-96. https://doi.org/10.1007/BF00975551

Schrenk, A., L. Gregoricka, D. Martin \& D. Potтs. 2016. Differential diagnosis of a progressive neuromuscular disorder using bioarchaeological and biogeochemical evidence. International Journal of Paleopathology 13: 1-10. https://doi.org/10.1016/j.ijpp.2015.12.004

Sheridan, S. 2017. Bioarchaeology in the ancient Near East: challenges and future directions for the southern Levant. Yearbook of Physical Anthropology 162: 110-52. https://doi.org/10.1002/ajpa.23149

Sheridan, S. \& L. GREgoricKa. 2015. Monks on the move: evaluating pilgrimage to byzantine $\mathrm{St}$ Stephen's monastery using strontium isotopes. American Journal of Physical Anthropology 158: 581-91. https://doi.org/10.1002/ajpa.22827

Shewan, L. 2004. Natufian settlement systems and adaptive strategies: the issue of sedentism and the potential of strontium isotope analysis, in C. Delage (ed.) The last hunter-gatherers in the Near East (British Archaeological Reports International series 1320): 55-94. Oxford: British Archaeological Reports.

Turner, T.S. 2012. The social skin. Journal of Ethnographic Theory 2: 486-504. https://doi.org/10.14318/hau2.2.026

(C) Antiquity Publications Ltd, 2019 
White, C., M. Spence, H. Stuart-Williams \& H. Schwarcz. 1998. Oxygen isotopes and the identification of geographical origins: the valley of Oaxaca versus the valley of Mexico. Journal of Archaeological Science 25: 643-55. https://doi.org/10.1006/jasc.1997.0259

White, C., F.J. Longstaffe \& K.R. Law. 2004. Exploring the effects of environment, physiology and diet on oxygen isotope ratios in ancient Nubian bones and teeth. Journal of Archaeological Science 31: 233-50. https://doi.org/10.1016/j.jas.2003.08.007

Wilkinson, J. 2002. Jerusalem pilgrims before the Crusades. Warminster: Aris \& Phillips.
WRIGHT, L. 2005. Identifying immigrants to Tikal, Guatemala: defining local variability in strontium isotope ratios of human tooth enamel. Journal of Archaeological Science 32: 555-66. https://doi.org/10.1016/j.jas.2004.11.011

Wright, L. \& H. Schwarcz. 1998. Stable carbon and oxygen isotopes in human tooth enamel: identifying breastfeeding and weaning in prehistory. American Journal of Physical Anthropology 106: 1-18. https://doi.org/10.1002/(SICI)10968644(199805)106:1<1::AID-AJPA1>3.0. CO;2-W

Received: 12 March 2018; Revised: 2 July 2018; Accepted: 23 July 2018 